\title{
Regional factors and innovativeness: an empirical analysis of four German industries
}

\author{
Tom Broekel · Thomas Brenner
}

Received: 18 August 2009 / Accepted: 18 December 2009 / Published online: 12 January 2010 (C) The Author(s) 2010. This article is published with open access at Springerlink.com

\begin{abstract}
A growing body of work emphasizes the importance of regional factors for regional innovativeness. In this paper, about 70 variables approximating the social-economic characteristics of regions are aggregated to 12 regional factors. In four industry-specific set-ups their influence on firms' innovativeness is tested. The study confirms that inter-industrial differences exist in the importance of these factors. In the empirical analyses a log-linear model is compared with a linear approach. While both are theoretically problematic it is shown that the log-linear model performs better in the empirical assessment.
\end{abstract}

Keywords Regional innovation performance $\cdot$ Regional innovativeness $\cdot$ Knowledge production function · Industry comparison · German regions

JEL Classification $\quad \mathrm{O} 18 \cdot \mathrm{R} 11 \cdot \mathrm{R} 12$

\section{Introduction}

The spatial component of innovation has attracted much attention in the literature. The question why some regions are more innovative than others is particularly addressed. Among others the answer is found in regional characteristics, e.g., a region's

T. Broekel (凶)

Section of Economic Geography, Faculty of Geosciences, Utrecht University,

Heidelberglaan 2, 3584 CS Utrecht, The Netherlands

e-mail: t.broekel@geo.uu.nl

T. Brenner

Economic Geography and Location Research, Philipps University Marburg,

Deutschhausstr. 10, 35032 Marburg, Germany

e-mail: thomas.brenner@staff.uni-marburg.de 
endowment with specific factors (Jaffe 1989; Anselin et al. 1997). The spatial proximity to certain actors and the embeddedness into certain regional structures "... promotes information transfer and spill-overs that lower the costs and reduce the risks associated with innovation" (Feldman and Florida 1994, p. 214).

Given the influence of these regional factors on the innovation performance of local firms, it is important to identify precisely which factors matter. Here, the literature offers a wide range of studies that promote a variety of variables to be crucial. For example, regional factors such as human capital and the number of firms have been analyzed to play a role in this respect (see, e.g., Weibert 1999; Brenner 2004). However, usually studies in this field do not include all of the factors that are put forward, but analyze only selections of these. Such bears the risk of spurious correlation and misleading conclusions. There are few studies that include a larger bandwidth of variables, of which the work by Feldman and Florida (1994) is probably best known. In a similar manner, we consider more than 70 variables, which are aggregated to 12 regional factors. These are tested for their influence on regional innovativeness.

A number of recent studies show that the importance of regional factors varies between industries (Brenner 2004; Brenner and Greif 2006). The analyses are therefore conducted separately for four different industries. The study confirms the existence of such inter-industry differences. Besides the R\&D conducted in a region, the financial situation and the quality of the human capital turn out to be the most relevant factors.

The knowledge production function and its typical log-linear implementation has almost become standard in this type of research (Audretsch 1998). Its assumptions and applicability are seldom questioned or reviewed, though. By discussing the implications of the log-linear and a simple linear regression model the paper challenges the appropriateness of the log-linear model. Moreover, in the empirical assessment both approaches are employed and compared with respect to the satisfaction of the models' assumptions and the meaningfulness of their results. It is shown that both models are not optimal; the log-linear model, however, fits better to the employed cross-sectional data.

The paper proceeds as follows. In the next section we discuss the relationship between firms' innovativeness and the presence of regional factors. Section 3 compares the linear and the log-linear model theoretically and describes relevant technicalities. The employed data and its sources are presented in Sect. 4. The results of the multivariate regressions are discussed in Sect. 5. Section 6 concludes.

\section{Theoretical considerations}

\subsection{Regional characteristics}

Based on the observation that the innovative activity differs among regions that are part of the same national innovation system, the question of the source of this disparity is raised. The concept of regional innovation systems claims that a region's specific social-economic environment has a crucial impact on the firms' innovativeness located 
in it. For example, the region's specific endowment with economic factors, such as human capital, the existence of certain institutions, the activity of local authorities, as well as the interaction between actors in networks are argued to play a role in this context (Cooke 1992).

There are good arguments for the importance of the regional level in innovation processes (see, e.g., Fischer 2001; Broekel and Binder 2007). There is, however, no commonly accepted definition or precise understanding of the regional innovation system's elements. Many studies claim different regional actors and factors to be crucial for regional innovative performance. Most empirical studies base their choice of factors on theoretical arguments. The innovation process is, however, complex and for nearly any factor plausible arguments can be found that support its relevance. Not surprisingly, empirical studies do not find a common set of factors to be relevant. For example, factors, such as the presence of firms of a specific size (Stenke 2000; Brenner and Greif 2006), science institutions (ISI 2000; Soete et al. 2002), various kinds of human capital (Fröderer et al. 1998; Soete and Stephan 2003), financial resources (OECD 2000; Peter 2002), and spillover, cooperation, and networks (Pittaway et al. 2003), have been identified in the literature as being significantly related to regional innovativeness.

As a consequence, we conduct an empirical study that contains many variables and discuss for each of these variables the arguments and the empirical evidence that is available for its relevance. Our approach is primarily empirically driven and therefore spans different theories and schools of thoughts. We test the spatial co-location of regions' socio-economic characteristics and highly innovative firms.

Following the ideas of the national innovation system literature (see, e.g., Freeman 1987), Feldman and Florida (1994) define a 'regional technological infrastructure' including the agglomeration of firms in related industries, university R\&D, industrial R\&D, and business-service firms (Feldman and Florida 1994, S. 211). They also include a range of control variables, e.g., the population of the federal state and an index of geographic concentrations.

In this study, we follow their idea of testing simultaneously a large number of factors and consider more than 70 regional characteristics that can be, or have been, attributed to influence firms' innovation processes. Mainly because of methodological reasons these factors are condensed to 12 structural regional factors that describe a region's situation with respect to (a) firms' R\&D efforts, (b) characteristics of an industry in a region, (c) urbanization, (d) structure of employment, (e) economic structure, (f) presence of universities, (g) quality of human capital, (h) potential human capital, (i) presence of public research institutes, (j) financial situation, (k) firm founding, and (1) regional attractiveness. However, there is also a theoretical reason behind merging the factors into a number of structural categories: often the factors measure similar things in different ways. For example, the overall tax gains, the income tax gains, the trade tax gains, and the sales tax gains are strongly related to each other and measure all the financial resources in the region. It is not adequate to include them all into the analysis, but it is also unclear which factor matters. We therefore merge them into a joint variable.

Nevertheless, our analysis includes more different kinds of factors than the usual approaches in the literature. This makes our concept of regional factors broader than 
the 'technological infrastructure' by Feldman and Florida (1994) because we also include regional characteristics that do not correspond to an infrastructure concept.

Some factors are not included in our study. These are factors that cannot be measured quantitatively or for which no approximations are given in the available data. They regard mainly actors' interactions and sector-specific cultural foundations. For example, the 'innovative milieu' approach is built around the idea of a shared cultural base in terms of social-economic problems and solutions. Here, only the coherence of the production systems, the culture and the most important actors allow such a milieu and its positive impact on the innovation activity of local firms to develop (Camagni 1991). Also local as well as non-local networks and linkages are often claimed to play a crucial role for innovation processes (Boschma and ter Wal 2007). As we do not have data from which we can model inter-organizational linkages its role is not investigated in this study. ${ }^{1}$

In the following, the variables are presented that can be brought into a relationship with the level of regional innovativeness. Some of these variables share similar theoretical context and only describe the same underlying factor in different ways. We therefore group these variables sharing the same context. In total, 12 such regional factors are formed. These superordinate regional factors are seen as the relevant influences impacting firms' innovativeness.

\subsubsection{R\&D employees}

The most important element in innovation processes are creative minds. Organized in groups, teams or just by oneself, professional R\&D employees are the innovative entity in industrial innovation processes. They search for and recombine existing knowledge in order to generate innovative products that are in some cases patented. In regional innovation economics it is argued that a stimulating and supportive regional environment facilitates their innovation activities causing their productivity to differ systematically inter-regionally (Desrochers 2001). Hence, the R\&D employees can be considered the necessary resource for innovation processes, while the factors presented below represent supportive elements.

\subsubsection{Industry characteristics}

Some of the most prominent regional factors argued to influence firms' innovativeness relate to the industrial structure of regions (Feldman and Florida 1994). Following the arguments of Marshall (1890), agglomeration (localization) economies are frequently analyzed and found to stimulate innovation activities (Greunz 2004). In the later analysis we approximate this externality by the production specialization index of the industries' employment in a region. The effects of this externality might, however, also be related to the absolute number of employees working in an industry in a region (Brenner 2004). This number is therefore considered as well. In particular, in the cluster literature it is highlighted that a large population of firms in a region that are

\footnotetext{
1 See, however, the study by Broekel and Meder (2008) that empirically investigates the impact of cooperation behavior on regional innovation performance.
} 
active in the same industry is beneficial for these firms' innovation processes (Brenner and Greif 2006). In the light of this the absolute number of firms belonging to the industry under investigation is taken into account. It is still controversial whether larger firms or smaller firms are more innovative. In a regional context, however, the function of large firms as gatekeepers (Graf 2007) and the particular role of their headquarters for regional development (Feldman and Florida 1994) suggest to expect a positive relationship between the presence of large firms in a region and regional firms' innovativeness. The average firm size of an industries' firms in a region is used to approximate this characteristic.

\subsubsection{Urbanization}

It is widely accepted that firms located in larger cities have advantages in generating innovations (see, e.g., Frenkel and Schefer 1998). Urbanized regions are advantaged because of the higher average utilization of their public infrastructure. In addition, the availability of trained workers, the spatial proximity to potential cooperation partners, and a better access to relevant markets work in favor of firms located in highly urbanized regions (Koschatzky 2001). Spillovers between corporations, institutions, and other participants in innovation processes have a spatial component. The exchange of not codified knowledge is fostered by face-to-face contacts (Audretsch 1998) for which the likelihood of benefiting from such spillovers is higher in agglomerations. On the other hand, high urbanization also has disadvantages. A lower disposability of industrial estates and higher costs of labor and taxes tend to go along with a high population density (Nerlinger 1998).

To account for urbanization, we use dummy variables differentiating regions with urbanized centers, with cities, and rural areas (see, e.g., Brenner and Greif 2006). In addition, we include a number of variables that either measure the concentration of economic activity directly, such as the population density, nature related area per inhabitant, density of employees in employment, density of work places, type of region, or which measure something that is clearly related to the density of economic activity and the collection rate of communities for trade tax.

\subsubsection{Economy structure}

The variables assigned to this factor reflect the sectoral structure of a region. Patents are mainly generated in the secondary sector (manufacturing), i.e., if a region has a higher stake in the tertiary sector it has a disadvantage in generating relatively high numbers of patents. We include therefore the share of these two sectors and the gross added value per employee in these two sectors in the analysis. The share of employees in the business service sector measures additionally the local availability of business services, such as consultants, financial services, etc. They are expected to positively influence the patent activity of local firms (Preisl and Wurzel 2001).

The turnover per employee is a variable accounting for various factors. Among others it reflects the market success of regional products and measuring the ability of local firms to turn their inventions into innovations and selling them. This variable is 
also affected by firm size and agglomeration (Rohl 2000), which are expected to have positive impacts on patent activity.

\subsubsection{Available human capital}

Human capital is known to be crucial for innovation processes (see, e.g., Faggian and McCann 2006). The potential impact of the share of employees with low qualification and with high qualification is a frequently used measure of the quality of local human capital (Weibert 1999). In addition, apprentices are important for the diffusion and generation of knowledge (Soete et al. 2002). The number of courses at adult education centers represent the opportunities for off-the-job training, i.e., the approximation of the change of in-the-job human capital quality.

The number of school leavers with a qualification for university entrance is included as well, because it determines the quality of the apprentices in a region. In this sense, the variable is used as proxy for the quality of the young workforce that enters firms through apprenticeships.

\subsubsection{Structure of human captial}

A somewhat different issue is the structure of the regional workforce with respect to certain social-economic groups. It can be argued that young employees are especially relevant for innovation activity. They are representing creativity and ideas coming directly from the educational system into corporations, the so-called 'knowledge transfer via heads' 2 (ISI 2000).

The share of female employees and the share of potential employees in work, as well as the rate of unemployment approximate the extent to which the endowment of a region's human capital is used.

Commuting moreover impacts a region's human capital. The capability of a region to absorb human capital from other regions increases the quality of the overall human capital through selection and accumulation processes (Stenke 2000). To take this into account, the numbers of commuters moving into and leaving a region are included.

\subsubsection{Potential human captial}

While the previously presented variables deal mainly with the human capital active in the job, the following capture the potential human capital, i.e., the structure and quality of the future employment in a region.

It is unknown whether undergraduates and graduates are going to stay in the region after their education. In general, the geographic mobility of German graduates is limited (Mohr 2002). It can be argued that people will first look for employment in the region they live in. If they have to choose between equal jobs in different regions, they will prefer the job offered closest to their current location. Hence, the potential human

\footnotetext{
2 Translated by the author.
} 
capital approximates the regional human capital pool, from which firms can chose in the future.

The potential human capital impacts the quality of the active employees due to selection mechanisms and competition. For this reason, for example, the German government founded new universities in order to advance rural areas and regions lacking in infrastructure (Blume and Fromm 2000).

According to the German educational system, graduates are broken down into graduates of universities and the graduates of technical colleges. Because technical colleges are more often specialized in the same technological fields as local corporations (Beise and Stahl 1999) they should contribute stronger to firms' innovation activities.

Empirically assessing the importance of the various education fields has not been done in this literature strand. Hence, we can only speculate about the relationships. Math and natural science and engineering graduates are included in the study, because they are the researchers and engineers of the future. Their influence will likely depend on the industry analyzed. We also include graduates of economics. They are crucial during the founding process of a business, where services and consultants play an important role (Nerlinger 1998). Six variables approximate the number of graduates in a region differentiating between the graduates from technical colleagues and universities as well as between the three different educational fields. The total numbers of graduates of each educational field are considered as well.

\subsubsection{Presence of universities and technical colleges}

Universities and technical colleges provide qualified human capital and act as research institutions and cooperation partners. In this respect they are major players in innovation processes. In Germany, they represent approximately one-third of the overall R\&D capacities (ISI 2000) and are the core of formal and informal regional networks (Soete et al. 2002). In addition, they offer support for business foundations, consultants, use of laboratory equipment, and are important sources for spin-offs (ISI 2000).

Spillovers from universities and technical colleges to local firms are generated through various mechanisms, such as cooperation, master theses, internships, movement of employees, and informal contacts between employees. The benefits of these spillovers seem to decrease with increasing geographic distance (Beise and Stahl 1999; Adams 2002).

It is difficult to separate the two functions of these institutions from each other and measure independently the impact of the provision of human capital and of their function as research institutes on the patent activity of local firms. We argue though that the first may be stronger related to the number of graduates while the latter is rather based on the number of faculties in a region. Hence, the numbers of faculties from different scientific fields are totaled for every region. The data are disaggregated to universities and technical colleges because they differ in their local impact and their spatial reach. Usually, universities spend a larger share of their budget on research, varying between $30 \%$ for clinics and $60 \%$ for engineering faculties. For certain faculties of technical colleges this share is as low as 5\% (Beise and Stahl 1999).

At the same time, technical colleges have a stronger local focus and are more application oriented (Beise and Stahl 1999). This is one important reason for the fact that 
co-location with these institutions is of varying importance for different industries (Pavitt 1984).

\subsubsection{Public research institutions}

Public research institutions are naturally generating many patents themselves. However, in the context here their role as partners in cooperation, as emitters of a wide range of spillovers, as suppliers, and as customers are in the focus. Nicolay and Wimmers (2000) find that $82 \%$ of innovation firms have contacts to such institutes. Independent of firm size, two-thirds of these were referring to institutions located in the same region.

Another aspect is their importance for start-ups. The latter can share the laboratories of research institutes and find partners, customers, or suppliers in these institutions. Adding to that, public research institutions are themselves emitters of spin-offs, that are likely to be located close by (Nerlinger 1998).

Different industries prefer to cooperate with different institutions. Firms with a high R\&D intensity are more likely to cooperate with public research institutes, while firms having a middle R\&D intensity cooperate rather with universities and technical colleges (Spielkamp and Vopel 1998). For the industries included here, this implies a stronger relationship between public research institutes and ELEC as well as INSTR, because they show a higher R\&D intensity (Pavitt 1984).

The regional factor public research institutions consists of the numbers of researchrelated employees in research organizations in a region. We consider the 'big four' institutions in Germany: the Helmholtz Association, the Max Planck Society, the Fraunhofer Society, and the Leibnitz. Association. The Max Planck Society and the Fraunhofer Society are concentrated in the southwest of Germany and often located next to universities (ISI 2000). While the latter focuses on applied research, the first is stronger focused on basic research (Beise and Stahl 1999). In addition, the Helmholz Association consists of 14 large-scale institutes all over Germany. The institutes of the Leibnitz Association have been part of programs to help regions lacking in infrastructure, especially regions in the former GDR (ISI 2000).

\subsubsection{Financial facilities}

Firms' financial resources are constraint and so are their R\&D resources. External funding is therefore necessary for $R \& D$ projects. Variables belonging to the regional factor financial facilities are the gross domestic product per inhabitant and the wages $\&$ salaries in manufacturing, per employee. They account not only for the demand for new products but also for the availability of capital for investments into innovation activities.

Tax revenues indicate moreover the financial situation of the inhabitants and the local municipalities. The higher they are the more likely they can give grants to R\&D projects, start-ups, etc. In addition, the financial situation is relevant for the local demand for new products and services. The overall, income, trade, and sales tax gains per inhabitant are considered to approximate the regional wealth in terms of tax revenues. 
The relation between financial facilities, tax gains, and regional innovativeness is subject to a causality problem. This holds especially for public finances. Because innovative firms are more likely to generate profits, the income of communities through tax payments will rise. This is to be considered in the interpretation of the results.

\subsubsection{Founding situation}

The number of business foundations per inhabitant symbolizes an active and subserve economic climate in the region, which reduces the risks and increases the probability of realizing innovations. Besides this, founding a firm is one way of turning an invention into an innovation. Thus, good conditions for the foundation of businesses are an incentive for doing research in the first place. For this reason it is not surprising that Acs and Audretsch (1992) find a positive relationship between innovation activity and business registrations in regions.

Founding activities usually require investments. Small- and medium-sized enterprises (SME) need especially external financial resources. Reserved granting of credits is the most important constraint to innovation for SMEs von Reden and Struck (2002). However, external funding is sparse in Germany, implying that entrepreneurs will first use their private or family resources (Nerlinger 1998), and the resources provided by public programs. The programs by the KfW Bankengruppe (KfW banking group) are especially relevant. The multitude of regional and national programs makes it difficult to find acceptable data. The variable public subsidiaries per inhabitant tries to add up a variety of such programs.

Venture capital (VC) is also becoming increasingly important in Germany providing financial resources, guidance, consulting, and management expertise. These firms gain through contracting a partial control over the management (Baltzer 2000). In the USA, evidence was found that firms partly financed by VC are growing faster and have lower rates of bankruptcy (Soete and Stephan 2003). They apply more often for patents, but do not have a higher share of R\&D resources (OECD 2000). In Germany the market for venture capital is yet small in comparison with the Anglo-Saxon countries. Its importance should not be overestimated. The remarkable growth during recent years justifies including the number of offices of venture capital companies who are members of the German Venture Capital Association e.V. in the study.

As in the case of the financial situation, there is again a causality problem to the relation between venture capital facilities and the innovativeness of a region. If firms are very innovative, a lot of spin-offs or start-ups are likely to occur and the market becomes attractive for $\mathrm{VC}$-corporations. Again, this has to be kept in mind for this factor's results.

\subsubsection{Regions' attractiveness}

To attract highly qualified workers and keep them in the region, attractive occupations and pleasant surroundings in the sense of soft location factors, are beneficial (Stenke 2000). Often they are difficult to measure and are overlaid by 'hard' factors (Grabow et al. 1995). Their impact can be, nevertheless, considerable (Weibert 1999). The choice of variables for inclusion in the analysis is difficult because it is often not 
the quantity, but the subjectively perceived quality that is relevant. We account for this factor with the regions' endowments with beds in hotels, motels, and resorts. The recreation area per inhabitant is self-explanatory as well as the places in kindergartens per inhabitant. It has to be noted though that the latter is much larger in the territories of the 'Neue Lander', indicating a significant difference in the social infrastructure between the two parts of Germany (Brenke et al. 2002). Other variables that are considered here are the rate of persons moving into the region and leaving it in terms of changing residence. These indicate the attractiveness of a region with respect to job opportunities and the living situation.

\subsection{The technological dimension}

Although concepts like the regional innovation system might be seen as sector spanning, it is well known that innovation processes have a technological dimension. Innovativeness is also of varying importance for different industries (Pavitt 1984; Malerba and Orsenigo 1996). In empirical assessments this needs to be considered, in particular if innovations are approximated by patents because the relevance of patenting is highly industry dependent (Arundel and Kabla 1998). Commonly, control variables for the regional industry structure are added to the econometric model to account for this, which allows, however, only a conclusion whether a certain relationship between a regional factor and the innovativeness measure holds in general even when controlling for the industrial structure. What seems to be more interesting though is whether the relationship is the same in all industries or if there exist differences between industries. In order to get a hold on this issue, industry-specific analyses are required. Analyses that separately investigate industries and compare the results are though rather an exception (but see, e.g., Brenner and Greif 2006).

We follow them and investigate separately: chemistry (CHEM), transport equipment manufacturers (TRANS), manufacturers of electric and electronic devices (ELEC), and manufacturers of instruments, medical and optical equipment (INSTR). ${ }^{3}$ For these industries patenting represents an important property rights protection mechanism (Arundel and Kabla 1998). This ensures that the innovation measure captures most, or at least a significant share of, innovations in these industries. These industries are also known to be relatively R\&D intensive (Audretsch 1998; ISI 2000). This guarantees a sufficient number of patents in every region.

Pavitt (1984) classifies industries by the organization of their innovation activity and the characteristics of the base-technologies. Applying his categorization to the industries studied here, ELEC and CHEM are science based, implying a high relevance of strong connections to public science institutions. In contrast, TRANS is considered to be a scale-intensive industry. Here, the most important source of technological know-how are suppliers and consulting engineers which suggests that the innovation activity of TRANS should be positively affected by the agglomeration of

\footnotetext{
3 Please note that the terms 'sector' and 'industry' can be arbitrarily used in this context. For the sake of readability the term 'industry' is used in the remainder of the paper.
} 
firms and industries. In case of INSTR, which Pavitt (1984) characterizes as specialized suppliers, customers and users are more crucial for firms' innovation processes.

Note that we aim to examine whether importance of the considered factors for regional innovativeness differs between industries. Hence, we analyze four industries separately but include some variables in all analyses in the same way. Different industry-specific variables are used for the dependent variable, the R\&D employment, and industrial characteristics variables. The other regional factors are identical for all industries.

\section{Method}

\subsection{Functional form of regression approach}

In contrast to the frequently discussed topic which regional factors are relevant for innovation processes, less attention has been paid to the way their influence can be empirically analyzed. In the literature most commonly the relationship between regional innovativeness and regional factors is empirically studied using regression approaches. Based on the works of Griliches (1979) and Jaffe (1989) the relationship between these is argued to be described by a log-linear dependency (see, e.g., Feldman and Florida 1994; Acs et al. 2002). Borrowing from the neoclassic Cobb-Doublas type production function the idea is that the regional innovation 'output' is created from a number of factors that are multiplicatively connected:

$$
Y=d * X_{1}^{c_{1}} * X_{2}^{c_{2}} \cdots * X_{n}^{c_{n}} * u
$$

where $Y$ denotes the innovation output and $X_{1}$ to $X_{n}$ are the $n$ regional factors that are considered in the analysis. $c_{1}$ to $c_{n}$ are the coefficients denoting the strength of each factor's impact and $d$ represents a constant. The main attractiveness of this approach is that by taking the logarithm it can be estimated with a simple ordinary least square regression:

$$
\log (Y)=\log (d)+\log \left(X_{1}\right) * c_{1}+\log \left(X_{2}\right) * c_{2}+\cdots+\log \left(X_{n}\right) * c_{n}+\log (u) .
$$

The assumption of a log-normally distributed error term is theoretically quite doubtful but commonly assumed for practical reasons (Chatterjee and Price 1995). Another advantage of this type of function is that the coefficients can be interpreted as elasticities. However, besides these advantages, there is no particular reason for why the relationship between innovative output and regional factors should be log-linear. Indeed, in very frequent cases this type of function delivers theoretically implausible results. For example, commonly the innovation output is frequently measured by patents, which to a great extent come from firms. Let us now assume that the number of firms, university graduates numbers, and employees of public research institutes are included in the analysis as regional factors. They are to be tested for their influence on regional innovativeness. If applying a log-linear knowledge production function 
one implicitly assumes that in a region with many firms and some public research but no university graduates no innovations have to be expected. This is because in the non-transformed version the regional factors are connected multiplicatively and a zero value in one implies that no innovative output is to be expected. This is clearly unrealistic. $^{4}$

This problem can be overcome by assuming a simple linear relationship with additively connected regional factors which is also found in the literature (see, e.g., Weibert (1999))

$$
Y=d+b_{1} X_{1}+b_{2} X_{2}+\cdots+b_{n} X_{n}+u,
$$

where $Y$ denotes again the innovation output and $X_{1}-X_{n}$ are the $n$ regional factors that are considered in the analysis. $b_{1}-b_{n}$ are the regression coefficients that denote the strength of each factors' impact. $d$ is a constant. $u$ is the statistical error term with the usual characteristics. From an application-oriented view this approach is comfortable and the factors can also be meaningfully interpreted. In contrast to the log-linear model, the linear approach would predict a positive number of innovations in the previously mentioned case of a region with no university graduates. In case of a region with no firms, but some graduates and public research, this model still predicts a positive innovation number. This is also not adequate because with no firm R\&D efforts we would rather suspect (and will likely see in reality) no innovations at all. The reason for this is that if one measures the innovation output of firms the existence of firms is a necessary condition. Note that we do not take innovations by other actors in a region into account, e.g., public research institutes. Studies in this field mainly aim at determining the impact of public research on firms' innovation performance and not the other way around. Hence, it is to be analyzed whether regional factors help firms to generate more or less innovations and not whether the innovative output of all regional actors is increased. This basic and simple insight is, however, seldom discussed in the literature.

From the aforementioned it becomes clear that both types of approaches are not perfect. One may say that the linear approach is more appropriate in 'extreme' situations, i.e., situations in which regional factors (that are not related to the presence of firms) show extreme low (zero) values. This is frequently the case because in many regions there are, e.g., no universities implying to expect zero innovation in the log-linear model. However, in 'moderate' situations, i.e., all regional factors have positive values, the log-linear model might be more appropriate. It is thus the aim of this paper to empirically compare these two models, which are both not optimal from a theoretical point of view, to get an insight on which fits the observed empirical patterns better.

The relationship between the regional factors and regional innovativeness is estimated twice for each industry. First, the standard linear regression model is applied and second the log-linear model. In order to test which model is more suitable it is checked whether the assumptions for their application are fulfilled. In addition, two

\footnotetext{
${ }^{4}$ In practice a small constant is added to zero values, for which, however, no theoretical justification is provided.
} 
exact tests are conducted verifying which model is more appropriate. To be more precise, the diagnostics of the two models include the standard issues as multicolinearity, heteroskedasticity, spatial autocorrelation, mis-specification, and the check for normally distributed error terms. Diagnostics for multicollinearity are done by the variance inflation factors (VIF) for each of the independent variables, (see Greene 2000). According to informal rules of thumb applied to the VIF, there is evidence of multicollinearity if the largest VIF is greater than 10 (see Chatterjee and Price 1995), or more conservative if it is larger than five. Heteroskedasticity is tested with the BreuschPegan test (Breusch and Pagan 1979). In case that the heteroskedasticity hypothesis cannot be rejected, robust (hc03) standard errors are estimated (Long and Ervin 2000). Spatial autocorrelation are tested with the LM test for error dependence (LMerr), the LM test for a missing spatially lagged dependent variable (LMlag). It is also tested if the variants of LMerr and LMlag are robust to the presence of the respective other (RLMerr, RLMlag) (see Anselin et al. 1996). For the estimation we consider a maximum range of potential spillovers of $300 \mathrm{~km}$ (Bottazzi and Peri 2003). Normality of the error term is analyzed with the robust Jarque-Bera test (Jarque and Bera 1980; Gel and Gastwirth 2008). General model mis-specification, e.g., omitted variables, are tested with Ramsey's regression equation specification error test (RESET) (Ramsey 1969).

The two exact tests for evaluating which model is more appropriate are the Bera-McAleer test (BM test) introduced by Bera and McAleer (1989) and the PE test which was developed by MacKinnon et al. (1983). Comparing both models with these tests requires in principle that all previously mentioned assumptions are met for such models, which is unlikely, as, e.g., in the case that the log-linear model is appropriate this implies that the relationship between regional factors and the innovativeness measure is non-linear. In the linear model, this will likely cause heteroscedasticity problems and non-normally distributed error terms. Hence, the fulfillment of the assumption will already give a strong hint at the results of two exact tests.

Last but not least a plausibility check is done. Based on the arguments presented in Sect. 3 the variables approximating industrial R\&D need to be significant.

Some more remarks on the data have to be made. As will be shown in Sect. 4, the depended variable is per definition a continuous and non-negative value, including some 'zero-values', which makes a tobit-regression or truncated model an adequate choice (Wooldridge 2003). However, there are only two 'zero-values' in the dependent variable in CHEM and one in ELEC. The two other industries' dependent variables are strictly positive. In addition, using a tobit-regression we cannot control for heteroscedasticity, which will turn out to be frequently present in the linear model. Also, the $\mathrm{BM}$ and PE tests are only defined for standard ordinary least square techniques. We therefore stick to the OLS approach. Nevertheless, tobit models have been estimated and found to confirm the results of the OLS estimation.

\subsection{Reducing dimensionality}

More than 70 independent variables have been presented and grouped according to shared theoretical contexts. These contexts are what we call regional factors, i.e., these 
are underlying factors that impact regional innovativeness. Official statistics seldom measure such factors in a single variable, e.g., the quality of human capital in a region. Most of the provided variables rather capture some but not all of parts of this factor. In other words, the provided information by the statistical offices do not match completely the theoretical factors that are put forward in the literature to impact regional innovativeness.

We solve this problem by employing a principal component analysis. This analysis extracts the statistical variance common to the variables assigned to one regional factor. We assume the largest part of the variance that can be extracted in one variable (first component) to be an appropriate measure of that regional factor. Note that we use this method to construct an index value representing most of the considered variables' information, which is slightly different from standard principal component analysis. ${ }^{5}$

We employ the principal component analysis on 11 of the 12 theoretically motivated factors. In case of R\&D employment this is not necessary because it is defined by the sum of an industry's R\&D employees. The first component then is used as an approximation of the regional factor.

One could have used the principal component analysis also to directly generate the regional factors. In this case the analyses is applied to all variables and a certain number of components are generated based on their shared statistical variance alone. In our eyes this approach is inferior to the chosen one because it bears the danger of obtaining components that are theoretically not meaningful. The reason is that variables might be spatially correlated although they do not refer to the same theoretical context.

In our case, the regional factors are created on a theoretical basis ensuring that each of the resulting first components has a consistent theoretical meaning. In Table 1 the variance covered by the first component for each regional factor is presented.

Except for the regional factor urbanization, research institutes, and founding situation, the covered proportion of variance is very high. Even in the mentioned cases it stays well above $60 \%$ though. The created factors cover by and large most of the included variables' information.

Some of the so-created regional factors contain zero values, which prevent taking the logarithm, which is necessary for the log-linear model. As suggested by Feldman and Florida (1994) all regional factors are therefore beforehand transformed by

$$
\tilde{X}=10 *(X+1) \text {. }
$$

\section{Data sources}

As an approximation of a region's innovation output we use the patent applications of the year 2000, published by the German patent office (Greif and Schmiedl 2002).

\footnotetext{
5 We use the standardized but not centered principal component analysis (PCA) because all our variables exhibit positive values and we are not interested in the differences to the mean but in an index representing the variables. This implies that the first component is driven by the mean function resulting in rather similar and strictly positive loadings.
} 
The spatial arrangement of patent applications relates to the residence of inventors. As regional units, the German planing regions (Raumordnungsregionen) are chosen dividing the country into 97 separate regional units. These regions are formed on a basis that takes into account the geographic nature of such economic functions as commuter flows, which have been identified to crucially influence patent statistics (Deyle and Grupp 2005). Thus, the chosen spatial unit offers an adequate way to analyze the link between the social-economic endowment of such a region and patent data.

Aware of the strengths and weaknesses of the information provided by patents (see, e.g., Feldman and Florida 1994; Deyle and Grupp 2005), we will use them as dependent variables in this study. Based on the categorization of the patent data, we use the sum of patent applications from corporations and private persons. This excludes the patent applications of public science institutions that would potentially bias the results. This bias results from the trivial fact that the more science institutions are located in a region the more patents of this category will be applied for.

In a cross-section analysis, time lags between the effects of a change in regional factors on the innovative output are observed to be a problem. This leads also to a causality problem because the ambient conditions of a region may have been influenced by the economic success of innovations in the past. This has to be considered when interpreting the results.

However, patent applications are of short-term and medium-term stability in volume as well as in spatial and industrial structure (Greif and Schmiedl 2002), for which we use social-economic data from the years 1999 and 2000.

The data used for constructing the regional factors are obtained form the German federal states' statistical offices. These data are jointly published as Easystat (2002). Moreover, the German Federal Office for Building and Regional Planning provides regional data (see INKAR 2002). The data of the R\&D employees are taken from the employment panel of the German Institute for Labor Market and Occupation Research.

We follow Bade (1987) and define R\&D employees as the occupational groups of engineers, chemists and natural scientists. ${ }^{6}$ The employment data are matched with the patent application using the concordance developed by Broekel (2007). This concordance is based on the concordance of Schmoch et al. (2003), but is also adapted to our data sources. Table 2 provides the industries' definitions in terms of patent classes and NACE codes.

\section{On the specification of the regression models}

\subsection{Linear versus log-linear approach}

The results for all industries and the two different models are presented in Tables 3 and 4 in the Appendix. For all linear and log-linear models multicollinearity is of some relevance. In the original models the VIF is always well below 10 . If we apply a benchmark of 5, in some models financial situation and economic structure as well as

\footnotetext{
6 Bade (1987) defines R\&D workers as employees belonging to the occupational groups 032, 60, 61 or 883 of the German occupation classification (IAB 2008).
} 
the human capital cause multicollinearity effects. It appears though that the financial situation carries most of the (negative) effect related to the economic structure. Multicollinearity between the two variables causes the sign of the coefficient of economic structure to change from negative to positive when the financial situation is excluded. The same applies to some human capital variables (potential human capital and universities). We focus on the results obtained with the variables that are most strongly related to regional innovativeness, which are in these cases the financial situation and the potential human capital.

There are serious signs of spatial autocorrelation in the TRANS models. To deal with this requires the use of spatial regression techniques (see, e.g., Anselin 2005) One aim of the paper is, however, to compare the linear and the log-linear models on the basis of OLS techniques (the BM and PE test are only defined for OLS). We therefore refrain from applying spatial regression. The results for TRANS though have to be interpreted with care.

Heteroskedasticity turns out to be a major problem for all linear models. The Breusch-Pegan tests are highly significant in all four cases. The residuals are also significantly non-normally distributed (Jarque-Bera test). ${ }^{7}$ In addition, with exception of the log-linear model in INSTR, the RESET test suggests in all cases specification problems that relate to the observed heteroskedasticity. The latter is also true for some of the log-linear models. However, the significance levels of the RESET tests are much lower for the log-linear models than those for the linear models. We conclude that in the log-linear models heteroskedasticity is not a serious problem. From an econometric point of view the latter seems to be the preferable approach for this data because the assumptions of the estimation procedure (OLS) are strongly violated in the linear model.

The log-linear model does not seem to be the optimal choice, though. In all but one case the RESET tests point at specification problems that might be caused by missing but relevant variables (Ramsey 1969). This is unlikely because the most important variables determining the number of patent applications in a region-R\&D employment-as well as a large number of other important variables are included in the analyses. The models additionally predict fairly well regional innovativeness (high $R^{2}$ ). We suspect therefore that the assumption of a log-linear functional relationships is not correct. This is also backed by the observation of the somewhat non-normally distributed error terms (at a low significance levels).

Further evidence for the better fit of the log-linear model is provided by the BM and PE tests. Except for CHEM the BM test yields supportive results for the log-linear model. The results of the PE test add to this in case of INSTR. In the other cases it is inconclusive. The results favoring the log-linear model, moreover, achieve higher significance levels than those backing the linear model.

For all models the $R^{2}$ are sufficiently high. As pointed out earlier, a necessary model check is whether the estimated models are plausible and meet the theoretical predictions. In our case this implies that the R\&D variables are significant, which we find to be true in all relevant log-linear models. The rather low significance of R\&D

\footnotetext{
7 Note that the Jarque-Bera test also suggests non-normally (spatially) distributed residuals for the log-linear model of TRANS. This is likely a result of the spatial autocorrelation.
} 
in case of TRANS is caused by its comparatively high correlation with the financial situation $\left(r=0.41^{* * *}\right)$ and the economic structure $\left(r=0.29^{* * *}\right)$. Once either variable is excluded R\&D becomes highly significant.

Despite the problems regarding the specification of the log-linear functional relationship, the log-linear models fulfill the most important requirements. On their basis the role of regional factors for firms' innovativeness can be analyzed.

\subsection{Regional factors and innovativeness}

For CHEM only R\&D and the industrial characteristics are found to be crucial for regional innovation performance. This suggests that for this industry most regional factors are not relevant. The still high $R^{2}$ results from the very high explanatory power of R\&D. Its standardized coefficient (beta value) clearly dominates all the others, indicating that this variable's contribution to the explanatory power of the model is largest. This is more or less the same for the other industries. In contrast, the contribution of industrial characteristics is less strong, although significant. It suggests that this industry benefits from being agglomerated in regions, which corresponds to results of other studies (Brenner and Greif 2006; Broekel 2008).

One of the most interesting results is that a good financial situation turns out to be a highly significant factor in the regression models for ELEC, INSTR, and TRANS. This reflects the important role of the south-western regions, which are financially well situated and show a strong concentration of these industries. As we have pointed out earlier, cross-sectional analyses are troubled by a causality problem because it cannot be clarified whether innovativeness impacts the regional financial situation or the other way around. ${ }^{8}$ From a theoretical point of view, the literature points to the crucial role of the financial support for innovation projects, particularly in case of small firms (Christensen 2007). While TRANS is clearly dominated by large firms (see Brenner and Greif 2006), in ELEC and INSTR small and mediumsized firms are often innovation leaders. In their cases our results are in line with the literature.

Some more inter-industrial similarities show up in the importance of human capital. The quality of the available human capital seems to be important for all industries, particularly for ELEC, and INSTR. INSTR is characterized by a higher relevance of interactions with customers and suppliers (Pavitt 1984). If the customer industries' production facilities are located in the same region, knowledge exchange and interaction are easier established and maintained. The customer industries of INSTR can be considered as high-tech industries themselves. This implies that these industries demand and attract highly qualified human capital, which explains the significance of the available human capital variable. ELEC is a science-based industry itself (Pavitt 1984), explaining the strong results for the available human capital.

The science-based characteristic of CHEM and ELEC moreover imply that spatial proximity to universities and technical colleagues enhance innovation performance. We therefore expected to find significant variables that are related to the presence of

\footnotetext{
8 Instrumental variables approaches might be a solution in future work.
} 
universities and technical colleagues. This is only the case of INSTR for which the potential human capital has a positive effect. The non-significant coefficients in the other models are in line with the non-industry-specific study by Fritsch and Slavtchev (2007). Our variables that approximate the presence of universities in a region are based on the number of graduates and the number of faculties. These variables reflect mainly the size of the universities. Fritsch and Slavtchev (2007) show that the mere size of universities in terms of the number of employees or the regular budget has no effect on regional innovativeness. In this respect, our study confirms their general results for the four studied industries. While Fritsch and Slavtchev (2007) additionally show that the quality of universities' research activities impact regional innovativeness, we lack the data to test this here.

Similar to CHEM, we find industrial characteristics to be important for INSTR. The positive coefficient of this variable suggests that the firms' innovation activities benefit from being agglomerated regionally. This somewhat contrasts the results of Broekel (2008), especially the finding that localization externalities are not of high importance for this industry. However, this industry is known to form clusters with positive effects that go beyond mere localization externalities (see Brenner 2006). According to Brenner and Greif (2006), these benefits are likely being related to the local labor markets and cooperation activities.

The analyses generally highlight the importance for conducting industry-specific studies. As it turns out, the relationships between regional factors and innovativeness vary between industries. This questions some results of previous studies that account for the technological dimension to a limited extent. Their results most likely reflect differences in the regional industry mix. At the same time, this finding demands more research to be conducted verifying or rejecting the results of the non-industry-specific studies. For policy this implies that there are still large scientific gaps in the knowledge of how regional factors influence regional innovativeness. With respect to our study it clearly shows that the quality of the human capital is of uttermost importance. For two industries, chemicals and instruments, moreover co-location to other firms of the same industry are beneficial. In this respect the concentration of this industry in few regions seems recommendable.

\section{Conclusion}

The study analyzed key characteristics of the 97 German planning regions that are endowed with highly innovative firms. In contrast to many previous studies this was done taking a very broad set of regional characteristics into account. More than 70 variables have been considered that are argued to be potentially related to differences in regional innovativeness. They have been aggregated to 12 regional factors. Their influence was tested with a multivariate regression framework. In addition, the paper compared two different types of regression approaches: the linear and the log-linear model. It was argued that both are not optimal from a theoretical basis.

One of the most important outcomes of the present study is that the choice of the functional relationship defining the regression approach is far from being easy and deserves more attention. It was shown that it matters not only from an theoretical 
perspective but also in the empirical application. While the linear regression did not prove to be superior to the most commonly employed log-linear model, the comparison highlighted some weaknesses of the log-linear model. For example, in the log-linear models of two industries, the specification test (RESET) suggested that the model can be improved by adding further variables or allowing for non- log-linear relationships.

Despite the many studies conducted in this field, we argue that too little attention has been paid to the way regional innovativeness and its determinants should be empirically analyzed. This regards, for example, R\&D employment as a necessary component in innovation processes. In contrast to the other regional factors they are not substitutable, which is something not accounted for in standard regression approaches. The 'regional innovation efficiency approach' by Fritsch and Slavtchev (2006) and Broekel (2008)is promising in this respect, in which the impact of regional factors is tested on the relationship between the regional numbers of $\mathrm{R} \& \mathrm{D}$ employment and the observed innovative output.

While in the literature many studies in the field are done in a non-industry-specific way (e.g., Fritsch and Slavtchev 2005), recently it was argued that this can be regarded as a major shortcoming (Brenner and Greif 2006; Broekel and Brenner 2007; Broekel 2008). The present study adds to this by highlighting inter-industrial differences in the importance of specific regional factors. For example, for the chemical industry regional factors seem to be of low relevance. In contrast, the financial situation in a region can be positively associated with the innovativeness of the transport equipment, electrics and electronics, and precision and optical instruments industries. In case of the latter two, the regional endowment with human capital also plays a stimulating role. This role seems not to be related to the mere size of the universities present in the regions, which backs the not-industry-specific findings by Fritsch and Slavtchev (2007), but rather to the presence of other high-tech industries.

The characteristics of an industry in a region, e.g., degree of specialization, firm number, was found to play a role for the chemical industry as well as the manufacturers of precision and optical instruments, underlining again inter-industrial differences. Hence, while the regional innovation system approach might be considered as being sector-spanning in empirical investigations the sectoral dimension cannot be neglected.

This work marks a starting point for further research. It provides some suggestions for enhancement of future studies dealing with this subject. It also delivers industryspecific insights into the coherence between the endowment of a region with a crucial set of factors and the innovativeness of local firms. The analysis lacks a dynamic component, which would answer to what extent the variation of the identified factors have an impact on the firm's ability to generate patents over time. Also, the causality relationship can be explored in a more appropriate fashion if data are available for larger time spans.

\section{A Appendix}

See Tables 1, 2, 3 and 4 
Table 1 Results of principal component analysis

\begin{tabular}{ll}
\hline Regional factor & Proportion of variance \\
\hline Industry characteristics CHEM & 0.851 \\
Industry characteristics TRANS & 0.816 \\
Industry characteristics ELEC & 0.850 \\
Industry characteristics InSTR & 0.891 \\
Urbanization & 0.635 \\
Employment structure & 0.949 \\
Available human capital & 0.940 \\
Financial situation & 0.973 \\
Economy structure & 0.968 \\
Universities and technical colleagues & 0.739 \\
Potential human capital & 0.973 \\
Research institutes & 0.647 \\
Founding situation & 0.696 \\
Regional attractiveness & 0.857
\end{tabular}

Table 2 Definitions of industries

\begin{tabular}{llll}
\hline Industry & Technological fields $^{\mathrm{a}}$ & Industries $^{\mathrm{b}}$ & Control $^{\mathrm{c}}$ \\
\hline Chemistry & TF5, TF12, TF13, & DG24, DI26 & TF6, TF20, \\
& TF14, TF15 & & DF23 \\
Machine & TF1, TF2, TF3, TF7, TF8, DA15, DA16, DB17, & TF6, TF22, \\
Building & TF9, TF11, TF17, TF18, & DB18, DC19, DC20, & DM34 \\
& TF19, TF20,TF21, TF23, & DE21, DE22, DH25, & \\
& TF24, TF25 & DJ27, DJ28, DK29, DN36 & TF23, TF20 \\
Transport & TF10, TF22 & DM34, DM35 & \\
Equipment & & & DL33 \\
Electrics and electronics & TF27, TF28, TF29, & DL30, DL31, DL32 & \\
Medical and optical equipment & TF4, TF16, TF26 & DL33, DF23 & TF6, TF15, DL30
\end{tabular}

${ }^{a}$ As defined in Greif and Schmiedl (2002)

${ }^{\mathrm{b}}$ According to the GIC DESTATIS (2002)

${ }^{\mathrm{c}}$ Technological fields of industries which have to be controlled for

Table 3 Regression results CHEM and TRANS

\begin{tabular}{|c|c|c|c|c|c|c|c|c|}
\hline & \multirow{2}{*}{\multicolumn{3}{|c|}{$\frac{\text { Linear }}{\text { Model } 1}$}} & \multicolumn{5}{|l|}{ Log-linear } \\
\hline & & & & \multicolumn{3}{|l|}{ Model 2} & \multirow{2}{*}{$\begin{array}{l}\text { Model } 3 \\
\text { Coef }\end{array}$} & \multirow[t]{2}{*}{ Model 4} \\
\hline & Coef & Std. Err. & Beta & Coef & Std. Err. & Beta & & \\
\hline \multicolumn{9}{|l|}{ CHEM } \\
\hline (Intercept) & -1690.97 & 1425.53 & & $-11.76^{* * *}$ & 3.8 & & $-12.58^{* * *}$ & \\
\hline $\mathrm{R} \& \mathrm{D}$ & $0.1^{* * *}$ & 0.02 & 0.93 & $0.03^{* * *}$ & 0 & 0.61 & $0.03^{* * *}$ & \\
\hline CHEM_Ind & -4.11 & 8.66 & -0.05 & $0.6^{*}$ & 0.35 & 0.13 & $0.63^{*}$ & \\
\hline
\end{tabular}


Table 3 continued

\begin{tabular}{|c|c|c|c|c|c|c|c|c|}
\hline & \multirow{2}{*}{\multicolumn{3}{|c|}{$\frac{\text { Linear }}{\text { Model } 1}$}} & \multicolumn{5}{|l|}{ Log-linear } \\
\hline & & & & \multicolumn{3}{|l|}{ Model 2} & \multirow{2}{*}{$\begin{array}{l}\text { Model } 3 \\
\text { Coef }\end{array}$} & \multirow[t]{2}{*}{ Model 4} \\
\hline & Coef & Std. Err. & Beta & Coef & Std. Err. & Beta & & \\
\hline Urbanization & 15.31 & 14.09 & 0.08 & 0.56 & 0.84 & 0.04 & 0.62 & \\
\hline $\mathrm{HC}$ structure & 12 & 13.53 & 0.04 & 1.6 & 1.18 & 0.09 & 1.35 & \\
\hline Economy stru. & -12.48 & 23.23 & -0.04 & 1.63 & 1.8 & 0.08 & 2.14 & \\
\hline Financial sit. & 6.55 & 9.16 & 0.06 & 0.19 & 0.72 & 0.03 & 0.20 & \\
\hline Universities & 1.32 & 2.99 & 0.03 & -0.09 & 0.28 & -0.04 & 0.17 & \\
\hline HC potential & 1.63 & 3.86 & 0.04 & 0.32 & 0.29 & 0.13 & & \\
\hline Research instit. & $-9.41^{*}$ & 5.15 & -0.19 & -0.05 & 0.2 & -0.02 & -0.03 & \\
\hline $\mathrm{HC}$ available & 20.29 & 23.34 & 0.05 & 2.68 & 1.7 & 0.12 & $3.15^{*}$ & \\
\hline Founding sit. & 21.08 & 14.48 & 0.11 & 0.06 & 0.62 & 0.01 & -0.04 & \\
\hline Regional attr. & 0.15 & 5.44 & 0 & 0.25 & 0.56 & 0.03 & 0.3 & \\
\hline Adj. $R^{2}$ & 0.90 & & & & 0.76 & & 0.76 & \\
\hline Max VIF & 6.57 & & & & 6.15 & & 2.97 & \\
\hline Sig. & $* * *$ & & & & $* * *$ & & & \\
\hline Obs. & 97 & & & & 97 & & & \\
\hline LMerr & 0.849 & & & & 0.532 & & & \\
\hline LMlag & 0.152 & & & & 0.144 & & & \\
\hline RLMerr & 1.453 & & & & 0.287 & & & \\
\hline RLMlag & 0.632 & & & & 0.000 & & & \\
\hline BP test & $38.531^{* *}$ & & & & 15.582 & & & \\
\hline RESET & $2.899^{*}$ & & & & $3.245^{* *}$ & & & \\
\hline Jarque-Bera & $351.452^{* * *}$ & & & & 1.688 & & & \\
\hline BM test & 0.012 & & & & -0.000 & & & \\
\hline PE & $25.32^{* *}$ & & & & $0.001^{*}$ & & & \\
\hline \multicolumn{9}{|l|}{ TRANS } \\
\hline (Intercept) & -1281.24 & 3365.8 & & -1.69 & 4.14 & & $-7.11^{*}$ & $-8.18^{*}$ \\
\hline $\mathrm{R} \& \mathrm{D}$ & $0.03^{*}$ & 0.02 & 0.83 & $0.01^{*}$ & 0 & 0.17 & $0.01^{* * *}$ & $0.01^{* * *}$ \\
\hline TRANS_Ind & 6.01 & 9.64 & 0.05 & $0.45^{*}$ & 0.24 & 0.13 & $0.42^{*}$ & 0.45 \\
\hline Urbanization & -14.19 & 26.66 & -0.04 & -0.61 & 0.92 & -0.05 & -1.12 & -0.93 \\
\hline HC structure & -19.55 & 32.62 & -0.04 & 1.08 & 1.26 & 0.06 & 1.11 & -0.78 \\
\hline Economy stru. & -59.04 & 57.4 & -0.11 & $-6.17^{* * *}$ & 2.08 & -0.33 & & $3.32^{*}$ \\
\hline Financial sit. & 9.04 & 44.51 & 0.05 & $5.72^{* * *}$ & 0.91 & 0.89 & $3.51^{* * *}$ & \\
\hline Universities & 4.93 & 13.31 & 0.07 & 0.44 & 0.33 & 0.19 & 0.47 & \\
\hline $\mathrm{HC}$ potential & -6.45 & 12.47 & -0.09 & -0.46 & 0.33 & -0.2 & & 0.14 \\
\hline Research inst. & -3.82 & 10.42 & -0.05 & -0.03 & 0.22 & -0.01 & -0.04 & -0.15 \\
\hline HC available & 103.68 & 85.37 & 0.16 & $3.44^{*}$ & 1.87 & 0.16 & $3.39^{*}$ & $5.53^{* *}$ \\
\hline Founding sit. & 33.19 & 25.05 & 0.1 & $-1.15^{*}$ & 0.68 & -0.13 & -1.1 & -0.63 \\
\hline Regional attr. & 0.98 & 10.92 & 0 & -0.35 & 0.58 & -0.04 & -0.5 & -0.91 \\
\hline Adj. $R^{2}$ & 0.8 & & & & 0.69 & & 0.65 & 0.55 \\
\hline
\end{tabular}


Table 3 continued

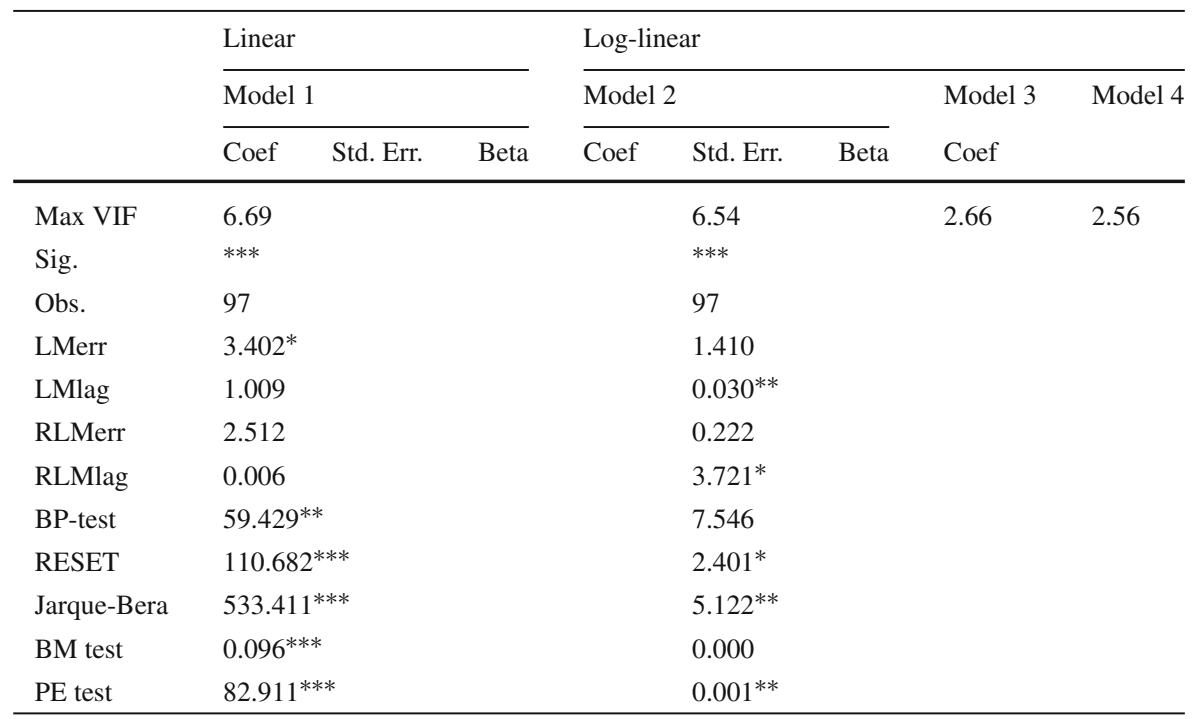

Signif. codes, $* * * 0.01 ; * * 0.05 ; * 0.1$

The coef and std err values of TRANS linear model represent the White's heteroskedasticity corrected standard errors

Table 4 Regression results ELEC and INSTR

\begin{tabular}{|c|c|c|c|c|c|c|c|c|}
\hline & \multirow{2}{*}{\multicolumn{3}{|c|}{$\frac{\text { Linear }}{\text { Model } 1}$}} & \multicolumn{5}{|c|}{ Log-linear } \\
\hline & & & & \multicolumn{3}{|l|}{ Model 2} & \multirow{2}{*}{$\begin{array}{l}\text { Model } 3 \\
\text { Coef }\end{array}$} & \multirow{2}{*}{$\begin{array}{l}\text { Model } 4 \\
\text { Coef }\end{array}$} \\
\hline & Coef & Std. Err. & Beta & Coef & Std. Err. & Beta & & \\
\hline \multicolumn{9}{|l|}{ ELEC } \\
\hline (Intercept) & -2539.35 & 2217.61 & & $-6.79^{*}$ & 3.81 & & $-10.6^{* * *}$ & $-13.79^{* * *}$ \\
\hline$R \& D$ & $0.03^{* * *}$ & 0.01 & 0.69 & $0.38^{* * *}$ & 0.08 & 0.4 & $0.42 * * *$ & $0.47^{* * *}$ \\
\hline ELEC_Ind & -3.49 & 13.6 & -0.03 & 0.09 & 0.27 & 0.02 & 0.16 & 0.41 \\
\hline Urbanization & -46.6 & 43.14 & -0.14 & -0.22 & 0.81 & -0.02 & -0.66 & -0.54 \\
\hline HC structure & 34.84 & 29.31 & 0.06 & 1.71 & 1.06 & 0.09 & 1.64 & 1.01 \\
\hline Economy str. & -13.26 & 55.25 & -0.02 & $-3.98^{* *}$ & 1.87 & -0.21 & & $3.03^{* *}$ \\
\hline Financial sit. & 17.12 & 27.47 & 0.09 & $3.58^{* * *}$ & 0.76 & 0.55 & $2.4^{* * *}$ & \\
\hline Universities & 4.01 & 7.16 & 0.06 & 0.35 & 0.28 & 0.15 & 0.14 & \\
\hline HC potential & -3.77 & 11.89 & -0.05 & -0.29 & 0.27 & -0.12 & & 0.25 \\
\hline Research inst. & 14.31 & 18.13 & 0.17 & 0.06 & 0.19 & 0.03 & 0.02 & -0.08 \\
\hline HC available & 36.3 & 55.01 & 0.06 & $5.11^{* * *}$ & 1.66 & 0.24 & $5.12^{* * *}$ & $6.53^{* * *}$ \\
\hline Founding sit. & 68.67 & 51.58 & 0.21 & -0.66 & 0.58 & -0.07 & -0.79 & -0.44 \\
\hline Regional attr. & -5.8 & 11.16 & -0.02 & -0.6 & 0.51 & -0.07 & -0.51 & -0.66 \\
\hline Adj. $R^{2}$ & 0.85 & & & 0.78 & & & 0.77 & 0.72 \\
\hline Max VIF & 6.57 & & & 6.2 & & & 2.71 & 2.69 \\
\hline Sig. & $* * *$ & & & $* * *$ & & & & \\
\hline Obs. & 97 & & & 97 & & & & \\
\hline
\end{tabular}


Table 4 continued

\begin{tabular}{|c|c|c|c|c|c|c|c|c|}
\hline & \multirow{2}{*}{\multicolumn{3}{|c|}{$\frac{\text { Linear }}{\text { Model } 1}$}} & \multicolumn{5}{|l|}{ Log-linear } \\
\hline & & & & \multicolumn{3}{|l|}{ Model 2} & \multirow{2}{*}{$\begin{array}{l}\text { Model } 3 \\
\text { Coef }\end{array}$} & \multirow{2}{*}{$\begin{array}{l}\text { Model } 4 \\
\text { Coef }\end{array}$} \\
\hline & Coef & Std. Err. & Beta & Coef & Std. Err. & Beta & & \\
\hline LMerr & $0.781^{*}$ & & & 0.349 & & & & \\
\hline LMlag & 0.806 & & & 0.416 & & & & \\
\hline RLMerr & 2.116 & & & 0.921 & & & & \\
\hline RLMlag & 2.082 & & & 1.031 & & & & \\
\hline PB test & $56.86^{* * *}$ & & & 19.272 & & & & \\
\hline RESET & $85.283^{* * *}$ & & & $2.420^{*}$ & & & & \\
\hline Jarque-Bera & $108.879^{* * *}$ & & & 0.318 & & & & \\
\hline BM test & $0.082^{* * *}$ & & & 0.000 & & & & \\
\hline PE test & $122.8^{* * *}$ & & & $0.000^{* * *}$ & & & & \\
\hline \multicolumn{9}{|l|}{ INSTR } \\
\hline (Intercept) & -1460.43 & 1480.05 & & 0.69 & 3.81 & & $-6.28^{*}$ & -4.27 \\
\hline $\mathrm{R} \& \mathrm{D}$ & 0.01 & 0.01 & 0.08 & $0.01^{* * *}$ & 0 & 0.23 & $0.01^{* * *}$ & $0.01^{* * *}$ \\
\hline INSTR_Ind & $8.17^{*}$ & 4.71 & 0.15 & $0.8^{* * *}$ & 0.27 & 0.21 & $1.07^{* * *}$ & $1.29^{* * *}$ \\
\hline Urbanization & 2.84 & 13.65 & 0.02 & 0.12 & 0.82 & 0.01 & -0.32 & 0.19 \\
\hline HC structure & -2.76 & 15.29 & -0.01 & -1.57 & 1.17 & -0.09 & -0.99 & $-2.26^{*}$ \\
\hline Economy str. & $-62.33^{* *}$ & 25.23 & -0.32 & $-6.52^{* * *}$ & 1.82 & -0.37 & & -1.18 \\
\hline Financial sit. & $28.72^{* * *}$ & 10.33 & 0.41 & $3.41^{* * *}$ & 0.76 & 0.57 & $1.32^{* *}$ & \\
\hline Universities & $6.64^{* *}$ & 3.29 & 0.25 & $0.51^{*}$ & 0.28 & 0.23 & & \\
\hline HC potential & -4.4 & 4.13 & -0.16 & -0.15 & 0.29 & -0.07 & $0.36^{*}$ & $0.42^{* *}$ \\
\hline Research inst. & 4.01 & 3.92 & 0.13 & 0.14 & 0.2 & 0.06 & 0.12 & 0.02 \\
\hline HC available & $68.1^{* *}$ & 31.91 & 0.29 & $4.66^{* * *}$ & 1.68 & 0.24 & $4.59^{* *}$ & $5.87^{* * *}$ \\
\hline Founding sit. & 23.51 & 14.35 & 0.19 & -0.92 & 0.6 & -0.11 & -0.92 & -0.63 \\
\hline Regional Attr. & -4.19 & 3.79 & -0.04 & 0.2 & 0.56 & 0.02 & 0.02 & 0.04 \\
\hline Adj. $R^{2}$ & 0.67 & & & 0.72 & & & 0.67 & 0.65 \\
\hline Largest VIF & 7.197 & & & 6.19 & & & 2.71 & 2.60 \\
\hline Sig. & $* * *$ & & & $* * *$ & & & & \\
\hline Obs. & 97 & & & 97 & & & & \\
\hline LMerr & 0.175 & & & 0.447 & & & & \\
\hline LMlag & 1.711 & & & 0.655 & & & & \\
\hline RLMerr & 0.158 & & & 0.535 & & & & \\
\hline RLMlag & 1.661 & & & 0.873 & & & & \\
\hline BP test & $18.127^{*}$ & & & 8.124 & & & & \\
\hline RESET & $18.962^{* * *}$ & & & 0.521 & & & & \\
\hline Jarque-Bera & $853.772^{* * *}$ & & & 3.201 & & & & \\
\hline BM test & $0.178^{* *}$ & & & 0.000 & & & & \\
\hline PE test & $30.332 *$ & & & 0.000 & & & & \\
\hline
\end{tabular}

Signif. codes, $* * * 0.01 ; * * 0.05 ; * 0.1$

The coef and std err values of ELEC and INSTR linear model represent the White's heteroskedasticity corrected standard errors 
Open Access This article is distributed under the terms of the Creative Commons Attribution Noncommercial License which permits any noncommercial use, distribution, and reproduction in any medium, provided the original author(s) and source are credited.

\section{References}

Acs Z, Audretsch D (1992) Innovationen durch kleine Unternehmen. Wissenschaftszentrum Berlin für Sozialforschung, Berlin

Acs ZJ, Anselin L, Varga A (2002) Patents and innovation counts as measures of regional production of new knoweldge. Res Policy 31:1069-1085

Adams JD (2002) Comparative localization of academic and industrial spillovers. J Econ Geogr 2(3):253278

Anselin L (2005) Exploring spatial data with GeoDa: a workbook. Center for Spatially Integrated Social Science

Anselin L, Bera AK, Florax R, Yoon MJ (1996) Simple diagnostic tests for spatial dependence. Reg Sci Urban Econ 26:77-104

Anselin L, Varga A, Acs Z (1997) Local geographic spillovers between university research and high technology innovations. J Urban Econ 42(3):422-448

Arundel A, Kabla I (1998) What percentage of innovations are patented? Empirical estimates for European firms. Res Policy 27(2):127-141

Audretsch D (1998) Agglomeration and the location of innovative activity. Oxf Rev Econ Policy 14(2)

Bade F-J (1987) Regionale Beschäftigungsentwicklung und produktionsorientierte Dienstleistungen. Sonderheft 143. Deutsches Institut für Wirtschaftsforschung, Berlin

Baltzer K (2000) Die Bedeutung des Venture Capital für innovative Unternehmen. Shaker Verlag, Aachen Beise M, Stahl H (1999) Public research and industrial innovations in Germany. Res Policy 28(4):397-422

Bera AK, McAleer M (1989) Nested and non-nested procedures for testing linear and nested and non-nested procedures for testing linear and log-lienar regression models. Indian J Stat 51:212-224

Blume L, Fromm O (2000) Regionalökonomische Bedeutung von Hochschulen. Kasseler Wirtschafts- und Verwaltungswissenschaften, Deutscher Universitäts Verlag, Wiesbaden, 11

Boschma RA, ter Wal ALJ (2007) Knowledge networks and innovative performance in an industrial district: the case of a footwear district in the south of Italy. Ind Innov 14(2):177-199

Bottazzi L, Peri G (2003) Innovation and spillovers in regions: evidence from European patent data. Eur Econ Rev 47(4):687-710

Brenke K, Geppert K, Hopf R, Pfeiffer I, Spies CK, Vesper D, Wagner GG (2002) Bausteine für die Zukunft Berlins. DIW-Wochenbericht 10/02.

Brenner T (2004) Local industrial clusters: existence, emergence and evolution. Routledge, London

Brenner T (2006) Identification of local industrial clusters in germany. Reg Stud 40(9):991-1004

Brenner T, Greif S (2006) The dependence of innovativeness on the local firm population an empirical study of German patents. Ind Innov 13(1)

Breusch TS, Pagan AR (1979) A simple test for heteroscedasticity and random coefficient variation. Econometrica 47:1287-1294

Broekel T (2007) A Concordance between Industries and Technologies - Matching the Technological Fields of the Patentatlas to the German Industry Classification. Jenaer Economic Research Papers, 2007-013.

Broekel T (2008) From average to the frontier: a nonparametric frontier approach to the analysis of externalities and regional innovation performance. Papers in Evolutionary Economic Geography 08.04

Broekel T, Binder M (2007) The regional dimension of knowledge transfers-a behavioral approach. Ind Innov 14(2):151-175

Broekel T, Brenner T (2007) Measuring regional innovativeness-a methodological discussion and an application to one German industry. DIME Working Paper 2007-13

Broekel T, Meder A (2008) The bright and dark side of cooperation for regional innovation efficiency. Papers in Evolutionary Economic Geography 08.11

Camagni R (1991) Local "Milieu", uncertainty and innovation networks: towards a new dynamic theory of economic space. In: Camagni R (ed) Innovation networks: spatial perspectives. Belhaven Stress, London

Chatterjee S, Price B (1995) Praxis der Regressionsanalyse, 2nd edn. R. Oldenbourg Verlag, München

Christensen JL (2007) Constraints on innovation finance in North Jutland, Denmark. Eur Plan Stud 15(9):1163-1180 
Cooke P (1992) Regional innovation sytems: competitive regulation in the new Europe. GeoForum 23:356382

Desrochers P (2001) Local diversity, human creativity, and technological innovation. Growth Change 32:369-394

DESTATIS (2002) Klassifikation der Wirtschaftszweige, Ausgabe 2003 (WZ2003). Statistisches Bundesamt, Wiesbaden

Deyle H, Grupp H (2005) Commuters and the regional assignment of innovative activities: a methodological patent study of German districts. Res Policy 34(2):221-234

Easystat (2002) Easystat—Statistik Regional, CD-Rom. Statistische Ämter der Länder des Bundes, Wiesbaden

Faggian A, McCann P (2006) Human capital flows and regional knowledge assets: a simultaneous equation approach. Oxf Econ Pap 52:475-500

Feldman MP, Florida R (1994) The geographic sources of innovation: technological infrastructure and product innovation in the United States. Ann Assoc Am Geogr 84(2):210-229

Fischer MM (2001) Innovation, knowledge creation and systems of innovation. Ann Reg Sci 35(2):199-216

Freeman C (1987) Technology and economic performance: lessons from Japan. Printer Publishers, London

Frenkel A, Schefer D (1998) Local milieu and innovations: some empirical results. Ann Reg Sci 32:185-200

Fritsch M, Slavtchev V (2005) The role of regional knowledge sources for innovation. Freiberg Working Papers 2005-15

Fritsch M, Slavtchev V (2006) Measuring the efficiency of regional innovation systems: an empirical assessment. Freiberg Working Papers 2006-6

Fritsch M, Slavtchev V (2007) Universities and innovation in space. Ind Innov 14(2):201-218

Fröderer K, Krey K, Palme K (1998) Innovation und Mittelstand, eine Umfrage bei 1871 Unternehmen. Beiträge zur Gesellschafts- und Bildungspolitik, Institut der Deutschen Wirtschaft, Köln

Gel YR, Gastwirth JL (2008) A robust modification of the Jarque-Bera test of normality. Econ Lett 99:30-32

Grabow B, Henckel D, Hollbach-Grömig B (1995) Weiche Standortfaktoren. Schriften des Deutschen Instituts für Urbanistik 89

Graf H (2007) Gatekeepers in regional networks of innovation. Jenaer Economic Research Papers 54

Greene WH (2000) Econometric nnalysis. Prentice Hall International (UK), London

Greif S, Schmiedl D (2002) Patentatlas 2002 Dynamik und Strukturen der Erfindungstätigkeit. Deutsches Patent- und Markenamt, München

Greunz L (2004) Industrial structure and innovation-evidence from European regions. J Evol Econ 14(5):563-592

Griliches Z (1979) Issues in assessing the contribution of R\&D to productivity growth. Bell J Econ 10:92116

IAB (2008) Sozialversicherungspflichtige Beschäftigte (ohne Personen in Ausbildung) und Arbeitslose. IAB Institut für Arbeitsmarkt- und Berufsforschung

INKAR (2002) Aktuelle Daten zur Entwicklung der Städte, Kreise und Gemeinden, CD-Rom, Berichte 8, vol 14. Bundesministerium fur Bauwesen und Raumplanung, Berlin

ISI (2000) Endbericht an das BMBF Regionale Verteilung der Innovations- und Technologiepotentialen in Deutschland und Europa. Fraunhofer Institut für Systemtechnik und Innovationsforschung, München,

Jaffe A (1989) Real effects of academic research. Am Econ Rev 79(5):957-970

Jarque C, Bera A (1980) Efficient tests for normality, homoscedasticity and serial independence of regression residuals. Econ Lett 6:255-259

Koschatzky K (2001) Räumliche Aspekte im Innovationsprozess. Wirtschaftsgeographie, vol 19. LIT, Munster

Long JS, Ervin LH (2000) Using heteroscedasticity consistent standard errors in the linear regression model. Am Stat 54:217-224

MacKinnon JG, White H, Davidson R (1983) Tests for model specification in the presence of alternative hypotheses: some further results. J Econ 21:53-70

Malerba F, Orsenigo L (1996) Schumpeterian patterns of innovation are technology-specific. Res Policy 25(3):451-478

Marshall A (1890) Principles of economics, (8th edn 1920). MacMillian, London

Mohr H (2002) Räumliche Mobilität von Hochschulabsolventen. In: Bellmann JL, Velling J (eds) Arbeitsmärkte fur Hochqualifizierte. Nürnberg, pp 249-281

Nerlinger E (1998) Standorte und Entwicklungen junger innovativer Unternehmen. Nomos Verlagsgesellschaft, Baden-Baden 
Nicolay R, Wimmers S (2000) Kundenzufriedenheit der Unternehmen mit Forschungseinrichtungen. Deutscher Industrie- und Handelstag (DIHT), Berlin

OECD (2000) A new economy? The changing role of innovation and information technology in growth. Information Society, OECD

Pavitt K (1984) Sectoral patterns of technical change: towards a taxonomy and a theory. Res Policy 13(6):343-373

Peter V (2002) Institutionen im Innovationsprozess. In: Technik, Wirtschaft, Politik. Schriftenreihe des Fraunhofer-Instituts für Systemtechnik und Innovationsforschung, Physica-Verlag, München

Pittaway L, Robertson M, Munir K, Denyer D, Neely A (2003) Networking and innovation: a systematic review of the evidence. Int J Manag Rev 5/6(3\&4):137-168

Preisl B, Wurzel U (2001) Zur Rolle der privaten und öffentlichen Forschungseinrichtungen in europaischen Innovationssystemen. DIW-Wochenbericht 30/01

Ramsey JB (1969) Tests for specification error in classical linear least squares regression analysis. J R Stat Soc Ser B 31:350-371

Rohl K-H (2000) Die Eignung der sächsichen Agglomerationsräume als Innovations- und Wachstumspole fur die wirtschaftliche Entwicklung des Landes. Diskussionsbeiträge aus dem Institut für Wirtschaft und Verkehr, No. 1/2000, Technische Universität Dresden, Fakultät für Verkehrswissenschaft, Dresden

Schmoch U, Laville F, Patel P, Frietsch R (2003) Linking Technology Areas to Industrial Sectors. Final Report to the European Commission, DG Research, Karlsruhe, Paris, Brighton

Soete B, Stephan A (2003) Nachhaltiges wirtschaftliches Wachstum durch Innovationen: Die Rolle von kleinen und mittleren Unternehmen. DIW-Wochenbericht 38/03

Soete B, Wurzel U, Drewllo H (2002) Innovationsnetzwerke in Ostdeutschland: Ein noch zu wenig genutztes Potential zur regionalen Humankapitalbildung. DIW-Wochenbericht 16/02

Spielkamp A, Vopel K (1998) Mapping innovative clusters in national innovation systems. ZEW Discussion Papers 98-45

Stenke G (2000) Großunternehmen in innovativen Milieus, Das Beispiel Siemes/München. Kölner Forschungen zur Wirtschaft-und Sozialgeographie 54

von Reden E, Struck J (2002) Nutzen und Wirkung öffentlicher Förderprogramme für Wachstumsunternehmen. In: Wertorientierts Start-Up Management. Verlag Franz Vahlen, München, pp 413-428

Weibert W (1999) Regionale Determinanten der Innovation. Nomos Verlagsgesellschaft, Baden-Baden

Wooldridge J (2003) Introductory econometrics a modern approach, (2nd edn). South Western Publshing, Mason 